\title{
Efficacy and safety of second-line agents for treatment of metastatic castration-resistant prostate cancer progressing after docetaxel. A systematic review and meta-analysis
}

\author{
Gianpaolo Perletti ${ }^{1,2}$, Elena Monti ${ }^{1}$, Emanuela Marras ${ }^{1}$, Anne Cleves ${ }^{3}$, Vittorio Magri ${ }^{4}$, \\ Alberto Trinchieri ${ }^{5}$, Paul S. Rennie ${ }^{6}$ \\ ${ }^{1}$ Biomedical Research Division, Dept. of Theoretical and Applied Sciences, Università degli Studi dell'Insubria, Busto Arsizio, Italy \\ 2 Department of Basic Medical Sciences, Ghent University, Ghent, Belgium; \\ ${ }^{3}$ Cancer Research Wales Library, Cardiff University Velindre Hospital, Cardiff, UK; \\ ${ }^{4}$ Urology Secondary Care Clinic, Istituti Clinici di Perfezionamento, Milano, Italy; \\ ${ }^{5}$ Urology Unit, A. Manzoni Hospital, Lecco, Italy; \\ ${ }^{6}$ Vancouver Prostate Centre, University of British Columbia, Vancouver, Canada.
}

\begin{abstract}
Summary Objective: We performed a systematic review of the literature to assess the efficacy and the safety of second-line agents targeting metastatic castration-resistant prostate cancer (mCRPC) that has progressed after docetaxel. Pooled-analysis was also performed, to assess the effectiveness of agents targeting the androgen axis via identical mechanisms of action (abiraterone acetate, orteronel).

Materials and Methods: We included phase III randomized controlled trials that enrolled patients with mCRPC progressing during or after first-line docetaxel treatment. Trials were identified by electronic database searching. The primary outcome of the review was overall survival. Secondary outcomes were radiographic progression-free survival (rPFS) and severe adverse effects (grade 3 or higher).
\end{abstract}

Results: Ten articles met the inclusion criteria for the review. These articles reported the results of five clinical trials, enrolling in total 5047 patients. The experimental interventions tested in these studies were enzalutamide, ipilimumab, abiraterone acetate, orteronel and cabazitaxel.

Compared to control cohorts (active drug-treated or placebotreated), the significant overall survival advantages achieved were 4.8 months for enzalutamide (hazard ratio for death vs. placebo: 0.63 ; $95 \%$ CI 0.53 to $0.75, P<0.0001$ ), 4.6 months for abiraterone (hazard ratio for death vs. placebo: $0.66,95 \%$ CI 0.58 to $0.75, P<0.0001$ ) and 2.4 months for cabazitaxel (hazard ratio for death vs. mitoxantrone-prednisone: 0.70 , $95 \%$ CI 0.59 to $0.83, p<0.0001$ ). Pooled analysis of androgen synthesis inhibitors orteronel and abiraterone resulted in significantly increased overall and progression-free survival for anti-androgen agents, compared to placebo (hazard ratio for death: $0.76,95 \%$ CI 0.67 to $0.87, P<0.0001$; hazard ratio for radiographic progression: $0.7,95 \%$ CI 0.63 to 0.77 , $P<0.00001)$. Androgen synthesis inhibitors induced significant increases in risk ratios for adverse effects linked to elevated mineralocorticoid secretion, compared to placebo (risk ratio for hypokalemia: $5.75,95 \%$ CI 2.08 to 15.90 ;

$P=0.0008$; risk-ratio for hypertension: $2.29,95 \%$ CI 1.02 to $5.17 ; P=0.05$ ).

Conclusions: In docetaxel-pretreated patients enzalutamide, abiraterone-prednisone and cabazitaxel-prednisone can improve overall survival of patients, compared to placebo or to best of care at the time of study (mitoxantrone-prednisone). Agents targeting the androgen axis (enzalutamide, abiraterone, orteronel) significantly prolonged $r P F S$, compared to placebo. Further investigation is warranted to evaluate the benefit of combination or sequential administration of these agents. Large-scale studies are also necessary to evaluate the impact of relevant toxic effects observed in a limited number of patients (e.g., enzalutamide-induced seizures, orteronel-induced pancreatitis, and others).

KEY WORDS: Castration-resistant prostate cancer; Hormone therapy; chemotherapy.

Submitted 15 March 2015; Accepted 31 March 2015

\section{INTRODUCTION}

Metastatic prostate cancer results from any combination of lymphatic, blood, or local spread, leading to various sorts of clinical presentations. The most common sites of metastasis are bone, lymph nodes and/or other visceral locations (1) At this stage of the disease, the first-line treatment is surgical or pharmacological androgen deprivation, to achieve castrate testosterone levels of $50 \mathrm{ng} / \mathrm{dL}$ or lower (2). Inevitably, the disease undergoes transition to castration-resistant prostate cancer (CRPC) (2).

In men with metastatic CRPC (mCRPC), docetaxel 75 $\mathrm{mg} / \mathrm{m}^{2}$ every 3 weeks, combined with low-dose corticosteroids, is the standard intervention $(3,4)$. However, in all patients the disease rapidly progresses to a docetaxelrefractory status, characterized by a time to progression of 3 months or less (5). Recently, new agents have been tested as second-line options in the post-docetaxel setting, in the frame of randomized phase III studies.

The present systematic review aimed to analyze the published evidence on post-docetaxel therapy for patients affected by mCRPC, in order to evaluate the efficacy and safety of novel treatments, compared with active drugs or placebo. Meta-analysis was also performed to evaluate 
the effect of agents targeting the androgen axis on survival, and to assess the adverse effects of treatment.

\section{MATERIALS AND METHOdS}

This review was prepared following the PRISMA checklist (5). MECIR criteria (http://editorial-unit.cochrane. org/mecir) were implemented whenever possible, within the word count limits established by the journal.

\section{Eligibility criteria}

We included phase III randomized controlled trials (RCT) that enrolled patients with mCRPC progressing during or after first-line docetaxel treatment. We included comparisons of an experimental systemic intervention with placebo or an active treatment, combined or not with a corticosteroid. We excluded from the present review (i) studies including post-hoc evaluations of RCTs, (ii) studies based on bone-targeting interventions aimed at palliating pain or preventing skeletal complications (e.g., radioisotopes, bisphosphonates, external beam radiation), (iii) studies including patients treated with protocols based on non taxane first-line agents, and (iv) studies investigating docetaxel-based therapies in the post-docetaxel setting (e.g., intermittent or combination therapies).

\section{Outcomes}

The primary outcome was overall survival, calculated from the date of randomization to death. Secondary outcomes were radiographic progression-free survival (rPFS), calculated between the date of randomization and the first date of radiographic progression, and adverse effects of grade 3 or higher.

\section{Search strategy and study selection}

Published study reports and supplementary material were identified by searching PubMed, MEDLINE, EMBASE, The Cochrane Library, Web of Science, BIOSIS, LILACS, other databases and trial registry platforms. Search strategies are available as on-line supplementary data to the present review. Database searches covered the period between January 2004 (the year docetaxel was first approved as first-line therapy for CRPC) and January 2015.

\section{Quality assessment}

The risk of bias (ROB) of included studies was assessed by three reviewers using the Cochrane Collaboration's tool (7). ROB was graded as high, low, or unclear.

Significant bias can be generated depending on how data are managed to estimate time-to-event endpoints like rPFS, where the exact time of progression is not known in most cases. In some studies, the date of death is imputed as the progression event. In others, rPFS is censored at the date of the last visit at which the patient is assessed to be progression-free. Studies adopting the latter approach were considered to be at low ROB (8), whereas for trials adopting other imputation strategies (i.e., date of first visit post-progression or death used to estimate progression) the risk of attrition bias was rated as high. Studies including patients who discontinued anti-androgen therapy ontrial were considered at high ROB (study design bias), due to the confounding effect of androgen withdrawal responses. The quality of the evidence resulting from pooled data analysis was evaluated using the GRADE framework, and reported in a summary of findings table (Table 3) (9).

\section{Data collection and statistical analysis}

Data extraction was performed by three reviewers. For time-to-event data, hazard ratios (HR) were extracted from study reports. To analyze grade $\geq 3$ adverse effects at specific study time points, the number of intent-totreat patients was extracted, and risk ratios (RR) were calculated. Analyses included the calculation of 95\% confidence intervals (CI). We analyzed only available information (available case analysis), without employing bias-prone data imputation strategies for missing data. For analysis of pooled data we used a fixed-effects model. Heterogeneity was assessed by calculating the $\mathrm{I}^{2}$ value. Given the small number of studies (two per metaanalysis) we did not employ formal methods to explore heterogeneity or to assess for publication bias. Data analysis was performed using the RevMan 5.3 software.

\section{RESULTS}

Results of the search and study inclusion A flow-chart of the search and screening process is shown in Figure 1. A total of 6518 publications were identified using our search strategy. From 36 potentially relevant articles selected by two independent reviewers on the

Figure 1. Study selection process for the present review. We retrieved total 6518 records from the following sources: MEDLINE (1483 records retrieved); EMBASE (1892 records retrieved); PubMed (314 records retrieved); The Cochrane Library (234 records retrieved); Web of Science (1313 records retrieved); BIOSIS (905 records retrieved); LILACS (15 records retrieved); WHO International Clinical Trials Registry Search Portal (362 records retrieved).

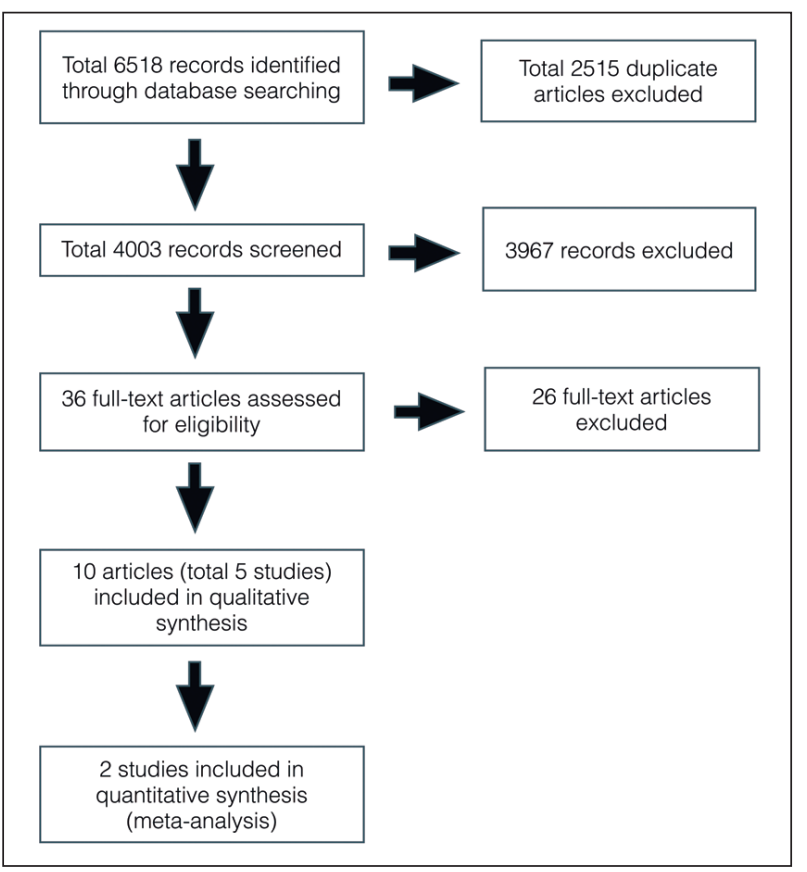


Table 1. Characteristics of included studies and baseline participant data.

\begin{tabular}{|c|c|c|c|c|c|}
\hline Study name $e^{\text {ref }}$ & AFFIRM (10) & CA184-043 (11) & COU-AA-301 (12) & TAK-700 (16) & TROPIC (17) \\
\hline Design & $\begin{array}{l}\text { Phase-lil, randomized, paralle } \\
\text { group, double-blind, placebo- } \\
\text { controlled trial. }\end{array}$ & $\begin{array}{l}\text { Phase-lil, randomized, parallel } \\
\text { group, double-blind, placebo- } \\
\text { controlled trial. }\end{array}$ & $\begin{array}{l}\text { Phase-lit, randomized, parallel group, } \\
\text { double-blind, placebo-controlled } \\
\text { trial. }\end{array}$ & $\begin{array}{l}\text { Phase-lit, randomized, parallel group, } \\
\text { double-blind, placebo-controlled } \\
\text { trial. }\end{array}$ & $\begin{array}{l}\text { Phase-lil, randomized, paralle } \\
\text { group, open-label, active drug- } \\
\text { controlled trial. }\end{array}$ \\
\hline $\begin{array}{l}\text { Total randomized } \\
\text { patients (n) }\end{array}$ & 1199 & 799 & 1195 & 1099 & 755 \\
\hline $\begin{array}{l}\text { Group 1, experimental } \\
\text { intervention } \\
\text { (n. patients } \\
\text { randomized) }\end{array}$ & $\begin{array}{l}\text { Enzalutamide, oral, } 4 \text { × } 40 \mathrm{mg} \\
\text { once-daily }(n=800)\end{array}$ & $\begin{array}{l}\text { Single dose of } 8 \text { Gy radiotherapy for } \\
\text { at least } 1 \text { and up to } 5 \text { bone fields, } \\
\text { followed by intravenous } \\
\text { ipilimumab, } 10 \mathrm{mg} / \mathrm{kg} \text {, every } 3 \\
\text { weeks for up to } 4 \text { doses ( } n=399 \text { ) }\end{array}$ & $\begin{array}{l}\text { Abiraterone acetate, oral, } 4 \text { × } 250 \\
\text { mg/day, for multiple } 28 \text {-day cycles, } \\
\text { plus prednisone, oral, } 10 \text { mg once- } \\
\text { daily ( } n=797 \text { ) }\end{array}$ & $\begin{array}{l}\text { Orteronel, oral, } 2 \times 400 \mathrm{mg} / \text { day } \\
\text { (Japanese patients: } 2 \times 300 \mathrm{mg} / \text { day), } \\
\text { for multiple } 28 \text {-day cycles, plus } \\
\text { prednisone, oral, } 5 \mathrm{mg} \text { twice-daily } \\
\text { ( } \mathrm{n}=734 \text { ). }\end{array}$ & $\begin{array}{l}\text { Cabazitaxel, intravenous, } 25 \\
\mathrm{mg} / \mathrm{m}^{2} \text { (1 hour infusion) every } 21 \\
\text { days, plus prednisone, oral, } 10 \mathrm{mg} \\
\text { once-daily ( } \mathrm{n}=378 \text { ) }\end{array}$ \\
\hline $\begin{array}{l}\text { Group 2, comparator } \\
\text { (control) intervention } \\
\text { (n. patients } \\
\text { randomized) }\end{array}$ & $\begin{array}{l}\text { Placebo, oral, } 4 \text { tablets once- } \\
\text { daily }(n=399)\end{array}$ & $\begin{array}{l}\text { Single dose of } 8 \text { Gy radiotherapy for } \\
\text { at least } 1 \text { and up to } 5 \text { bone fields, } \\
\text { followed by intravenous placebo } \\
\text { (0.9\% sodium chloride), every } 3 \\
\text { weeks for up to } 4 \text { doses ( } n=400 \text { ) }\end{array}$ & $\begin{array}{l}\text { Placebo tablets, oral, } 4 / \text { day, for } \\
\text { multiple } 28 \text {-day cycles, plus } \\
\text { prednisone, oral, } 10 \text { mg once-daily } \\
(n=398)\end{array}$ & $\begin{array}{l}\text { Placebo tablets, oral, } 2 / \text { day, for } \\
\text { multiple } 28 \text {-day cycles, plus } \\
\text { prednisone, oral, } 5 \mathrm{mg} \text { twice-daily } \\
(\mathrm{n}=365)\end{array}$ & $\begin{array}{l}\text { Mitoxantrone, intravenous, } 12 \\
\mathrm{mg} / \mathrm{m}^{2}(15-30 \text { min. infusion) every } \\
21 \text { days, plus prednisone, oral, } 10 \\
\mathrm{mg} \text { once-daily ( } \mathrm{n}=377)\end{array}$ \\
\hline Dropouts & $\begin{array}{l}\text { 189 (Group 1, 111; Group 2, } \\
78 \text { ) }\end{array}$ & 767 (Group 1, 379; Group 2, 388) & 287 (Group 1, 184; Group 2, 103) & 889 (Group 1, 583; Group 2, 306) & 144 (Group 1, 86; Group 2, 58) \\
\hline $\begin{array}{l}\text { Median age } \\
\text { (Group 1/Group 2) }\end{array}$ & $69 / 69$ & $69 / 67.5$ & $69 / 69$ & $69.5 / 70$ & $68 / 67$ \\
\hline $\begin{array}{l}\mathrm{ECOG}=0-1 \\
\text { (Group 1/Group 2) }\end{array}$ & $91 \% / 92 \%$ & $96 \% / 98 \%$ & $90 \% / 89 \%$ & $92 \% / 93 \%$ & $93 \% / 91 \%$ \\
\hline $\begin{array}{l}\text { ECOG = 2 (Group } \\
1 / \text { Group 2) }\end{array}$ & $9 \% / 8 \%$ & Exclusion criterion & $10 \% / 11 \%$ & $9 \% / 7 \%$ & $7 \% / 9 \%$ \\
\hline $\begin{array}{l}\text { Presence of baseline } \\
\text { visceral disease } \\
\text { (Group 1/Group 2) }\end{array}$ & $25 \% 21 \%$ & $28 \% 29 \%$ & $30 \% / 24 \%$ & $27 \% / 27 \%$ & $25 \% / 25 \%$ \\
\hline $\begin{array}{l}\text { BPI pain score >4 } \\
\text { (Group 1/Group 2) }\end{array}$ & $28 \% / 29 \%$ & $49 \% 47 \%$ & $45 \% / 45 \%$ & $\begin{array}{l}3.0 / 3.0 \\
\text { (median value) }\end{array}$ & $46 \% / 45 \%$ \\
\hline $\begin{array}{l}\text { Disease progression } \\
\text { within } 3 \text { months post- } \\
\text { docetaxel (Group } \\
\text { 1/Group 2) }\end{array}$ & ND & ND & $66 \% / 70 \%$ & ND & $42 \% / 48 \%$ \\
\hline $\begin{array}{l}\text { Previous hormone } \\
\text { therapy } \\
\text { (Group 1/ Group 2) }\end{array}$ & ND & $17 \% / 16 \%$ & $100 \% / 100 \%$ & $96 \% / 95 \%$ & $99 \% / 99 \%$ \\
\hline $\begin{array}{l}\text { Total Docetaxel dose } \\
\text { (Group 1/Group 2) }\end{array}$ & $600 / 600 \mathrm{mg} / \mathrm{m}^{2}$ & ND & $906 / 895 \mathrm{mg} / \mathrm{m}^{2}$ & ND & $576.6 / 529.2 \mathrm{mg} / \mathrm{m}^{2}$ \\
\hline
\end{tabular}

$E C O G=$ Eastern Cooperative Oncology Group Performance Status; BPI = Brief Pain Inventory Score; ND = Not Determined .

basis of title and abstract content, 10 articles met the inclusion criteria for the present review.

These articles report the results of five clinical trials: AFFIRM (enzalutamide versus placebo) (10), CA184-043 (ipilimumab versus placebo) (11), COU-AA-301 (abiraterone acetate/ prednisone versus placebo/prednisone) (12-15), TAK-700 (orteronel/prednisone versus placebo/ prednisone) (16), TROPIC (cabazitaxel/prednisone versus mitoxantrone/prednisone) (17-19). Table 1 summarizes the characteristics of the included studies, the experimental interventions and key baseline patient characteristics.

\section{Risk of bias in included studies}

Table 2 and Figure 2 summarize the ROB evaluations for the included studies. High ROB was assessed in few cases. The TROPIC trial was an open-label study, having high risk of selection and performance/detection bias. The AFFIRM trial was considered as presenting high risk of attrition bias, since a marked imbalance was found between censored PFS data in the placebo (62\%) and the enzalutamide (38\%) arms. In the CA184-043 and COUAA-301 studies, a high number of censored survival data suggests high risk of attrition bias. In the CA184-043 trial,

Figure 2. Risk of bias summary. Green circles represent low risk of bias; red circles represent high risk of bias; yellow circles represent unknown risk of bias.

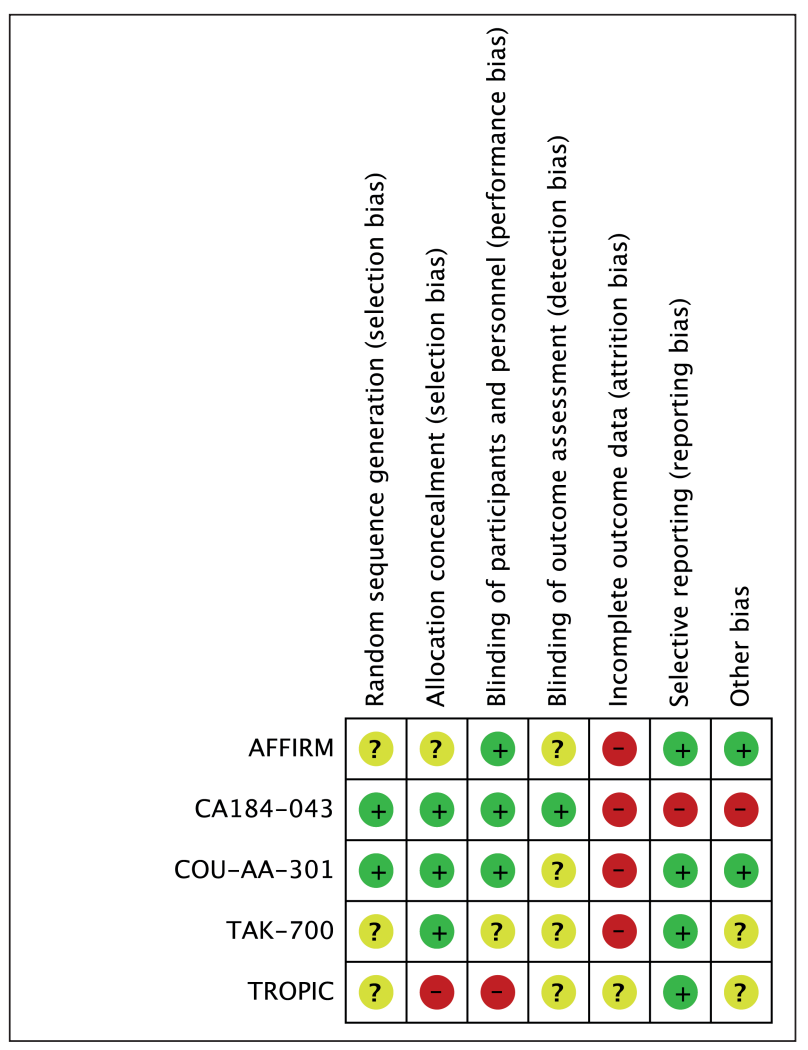


Table 2. Risk of bias (ROB) of the included studies.

\begin{tabular}{|c|c|c|c|c|c|}
\hline Study ID ret & AFFIRM (10) & CA184-043 (11) & COU-AA-301 (12) & TAK-700 (16) & TROPIC (17) \\
\hline $\begin{array}{l}\text { Random } \\
\text { sequence } \\
\text { generation }\end{array}$ & $\begin{array}{l}\text { Unclear. The study was be centrally } \\
\text { randomized by interactive voice } \\
\text { response system using a permuted } \\
\text { block method. No further details } \\
\text { are given about sequence } \\
\text { generation and size of patient } \\
\text { blocks. }\end{array}$ & $\begin{array}{l}\text { Low. Random assignment was done } \\
\text { with an interactive voice response } \\
\text { system; sufficient details on } \\
\text { randomization procedures have been } \\
\text { provided }\end{array}$ & $\begin{array}{l}\text { Low. Patients were randomly assigned } \\
\text { to treatment in a blinded manner by } \\
\text { centralized permuted block method } \\
\text { via an interactive web response } \\
\text { system. }\end{array}$ & $\begin{array}{l}\text { Unclear. Published details about } \\
\text { sequence generation or block size are } \\
\text { insufficient. }\end{array}$ & $\begin{array}{l}\text { Unclear. The dynamic allocation } \\
\text { system is not a random sampling } \\
\text { strategy in a strict sense. Candidate } \\
\text { patients are not allocated randomly; } \\
\text { their allocation is determined on the } \\
\text { basis of prognostic factors chosen as } \\
\text { inclusion criteria. }\end{array}$ \\
\hline $\begin{array}{l}\text { Allocation } \\
\text { concealment }\end{array}$ & $\begin{array}{l}\text { Unclear. A permuted block system } \\
\text { may allow foreknowledge of the } \\
\text { allocation in a number of patients, } \\
\text { in the absence of dynamic variation } \\
\text { of the block sizes throughout the } \\
\text { study. No details were given on } \\
\text { procedures adopted to minimize } \\
\text { the risk of selection bias. }\end{array}$ & $\begin{array}{l}\text { Low. An interactive voice response } \\
\text { system is a reliable allocation strategy } \\
\text { when managed by an independent } \\
\text { party. }\end{array}$ & $\begin{array}{l}\text { Low. Although a permuted block } \\
\text { system may allow foreknowledge of the } \\
\text { allocation in a number of patients, the } \\
\text { block size was chosen to minimize the } \\
\text { chance of accidental unblinding. }\end{array}$ & $\begin{array}{l}\text { Low. Patients were randomly assigned } \\
\text { to study treatments centrally by means } \\
\text { of an interactive voice response } \\
\text { system; we assume that allocation was } \\
\text { unknown and unforeseeable at the } \\
\text { single involved center level }\end{array}$ & $\begin{array}{l}\text { High. Patients and treating physicians } \\
\text { were not masked to treatment } \\
\text { allocation. }\end{array}$ \\
\hline $\begin{array}{l}\text { Blinding of } \\
\text { participants } \\
\text { and personnel }\end{array}$ & $\begin{array}{l}\text { Low. Placebo administration was } \\
\text { adequate, and all subjects, } \\
\text { investigators, and the sponsor's } \\
\text { staff involved in the conduct of the } \\
\text { study were blinded to treatment } \\
\text { assignment }\end{array}$ & $\begin{array}{l}\text { Low. The study funder, patients, and } \\
\text { site staff were masked with respect to } \\
\text { each patient's assignment until the } \\
\text { database cutoff date for this report. } \\
\text { The fact that pharmacists were not } \\
\text { masked is unlikely to have affected } \\
\text { overall masking. }\end{array}$ & $\begin{array}{l}\text { Low. The study sponsor, study } \\
\text { personnel, patients, and members of } \\
\text { IDMC remained masked to treatment } \\
\text { assignment until completion of study. }\end{array}$ & $\begin{array}{l}\text { Unclear. No mention is made of any } \\
\text { measures to ensure the blinding of } \\
\text { investigators and medical staff. There } \\
\text { is also no mention of where the } \\
\text { blinded database was held. }\end{array}$ & $\begin{array}{l}\text { High. The study had an open-label } \\
\text { design. Although survival, biochemical } \\
\text { findings and radiological evidence } \\
\text { could not be influenced by the open- } \\
\text { label setting, other endpoints (e.g., } \\
\text { pain, quality of life) could be prone to } \\
\text { performance bias. }\end{array}$ \\
\hline $\begin{array}{l}\text { Blinding of } \\
\text { outcome } \\
\text { assessment }\end{array}$ & $\begin{array}{l}\text { Unclear. The sponsor's staft } \\
\text { involved in the conduct of the study } \\
\text { was blinded to treatment } \\
\text { assignment. However, it was not } \\
\text { clear whether the independent } \\
\text { Data Monitoring committee } \\
\text { reviewing safety data was also } \\
\text { blinded to treatment assignment. }\end{array}$ & $\begin{array}{l}\text { Low. Until database lock, investigators } \\
\text { assessing disease progression } \\
\text { remained masked to treatment } \\
\text { allocation }\end{array}$ & $\begin{array}{l}\text { Unclear. The rationale for laboratory } \\
\text { personnel unblinding is not clearly } \\
\text { explained in the protocol or study } \\
\text { report. }\end{array}$ & $\begin{array}{l}\text { Unclear. There is no mention of } \\
\text { blinding of the personnel in charge of } \\
\text { assessing outcomes. It is also unclear } \\
\text { whether the independent data } \\
\text { monitoring committee was blinded to } \\
\text { treatment assignment. }\end{array}$ & $\begin{array}{l}\text { Unclear. Although the study team was } \\
\text { masked to treatment allocation and } \\
\text { patient outcomes throughout the trial, } \\
\text { an independent contract statistician } \\
\text { provided unmasked results to an } \\
\text { independent data monitoring } \\
\text { committee with the appropriate } \\
\text { analyses for assessment }\end{array}$ \\
\hline $\begin{array}{l}\text { Incomplete } \\
\text { outcome data } \\
\text { (attrition bias) }\end{array}$ & $\begin{array}{l}\text { High. There were more events } \\
\text { censored in the placebo arm (62\%) } \\
\text { than in the enzalutamide arm } \\
(38 \%) \text {. Differences in proportion of } \\
\text { incomplete outcome data across } \\
\text { groups may generate attrition bias. } \\
\text { In addition, rPFS was defined in the } \\
\text { protocol as first evidence of } \\
\text { radiographic progression or death } \\
\text { from any cause. }\end{array}$ & $\begin{array}{l}\text { High. A high number of censored } \\
\text { overall survival data suggests high risk } \\
\text { of attrition bias. }\end{array}$ & $\begin{array}{l}\text { High. The FDA medical review for } \\
\text { abiraterone indicated that most events } \\
\text { in the radiographic PFS analysis were } \\
\text { deaths rather than radiographic } \\
\text { progression (measured in } 27-30 \% \text { of } \\
\text { patients). Evaluation of rPFS was } \\
\text { heavily driven by the number of } \\
\text { deaths. Moreover, the fraction of } \\
\text { censored patients was unbalanced } \\
\text { between treatment arms (abiraterone: } \\
28 \% \text {; placebo: } 18 \% \text { ). }\end{array}$ & $\begin{array}{l}\text { High. Radiographic progression-free } \\
\text { survival was defined as time from } \\
\text { randomization to centrally confirmed } \\
\text { radiographic disease progression or } \\
\text { death from any cause. }\end{array}$ & $\begin{array}{l}\text { Unclear. No detailed information } \\
\text { about censoring rules were provided. }\end{array}$ \\
\hline $\begin{array}{l}\text { Selective } \\
\text { reporting } \\
\text { (reporting bias) }\end{array}$ & $\begin{array}{l}\text { Low. There appears to be no } \\
\text { reporting bias. }\end{array}$ & $\begin{array}{l}\text { High. The protocol specitied that a } \\
\text { statistical comparison of progression- } \\
\text { free survival was to be done only if the } \\
\text { groups differed significantly for overall } \\
\text { survival. Even though no significant } \\
\text { difference was found between groups, } \\
\text { the analysis was performed, and } \\
\text { considerable emphasis was placed on } \\
\text { results in the study report. }\end{array}$ & $\begin{array}{l}\text { Low. There appears to be no reporting } \\
\text { bias. }\end{array}$ & $\begin{array}{l}\text { Low. All outcomes specified in the } \\
\text { protocol are reported in the article }\end{array}$ & $\begin{array}{l}\text { Low. Outcomes and endpoints } \\
\text { indicated in the original protocol have } \\
\text { been reported }\end{array}$ \\
\hline $\begin{array}{l}\text { Other bias } \\
\text { (baseline } \\
\text { imbalances, } \\
\text { etc.) }\end{array}$ & $\begin{array}{l}\text { Low. A baseline imbalance concerning } \\
\text { the fraction of patients with highly } \\
\text { prognostic visceral metastases } \\
\text { favors the enzalutamide arm } \\
\text { (placebo: 25\%; enzalutamide: } \\
21 \% \text { ). }\end{array}$ & $\begin{array}{l}\text { High. All patients received a dose of } \\
\text { radiotherapy of } 8 \text { Gy for at least one, } \\
\text { and up to five, bone fields, at the } \\
\text { investigator's discretion. Moreover, } \\
\text { palliative radiotherapy was allowed for } \\
\text { any bone lesion while on study". Inter- } \\
\text { arm differences in radiotherapy might } \\
\text { interfere with survival outcomes. In the } \\
\text { CA184-043 study protocol, inclusion } \\
\text { criteria prescribe that patients must } \\
\text { have discontinued anti-androgens at } \\
\text { least } 2 \text { weeks prior to randomization. } \\
\text { This might bias study results due to } \\
\text { the induction of anti-androgen } \\
\text { withdrawal syndrome. }\end{array}$ & $\begin{array}{l}\text { Low. A baseline imbalance concerning } \\
\text { the fraction of patients with visceral } \\
\text { metastases favors the placebo arm } \\
\text { (placebo: } 24 \% \text {; abiraterone: } 30 \% \text { ). }\end{array}$ & $\begin{array}{l}\text { Unclear. Baseline imbalance between } \\
\text { cohorts was assessed for BPI-SF worst } \\
\text { pain score, > } 2 \text { chemotherapies prior } \\
\text { to study start, PSA and lactate } \\
\text { dehydrogenase levels. However, data } \\
\text { were not disclosed for these values, } \\
\text { and a comprehensive analysis is } \\
\text { impossible. }\end{array}$ & $\begin{array}{l}\text { Unclear. Baseline imbalances may } \\
\text { have biased some study results. In a } \\
\text { Iong-term survival analysis, it was } \\
\text { shown that } 18 \% \text { and } 9 \% \text { of patients in } \\
\text { the cabazitaxel and mitoxantrone } \\
\text { arms, respectively, were alive at the } 24 \\
\text { month time point (Bahl } 2013) \text {. At } \\
\text { baseline, the presence of visceral } \\
\text { metastases, highly prognostic for 0S, } \\
\text { was higher in the mitoxantrone arm } \\
(20 \%) \text {, compared to cabazitaxel } \\
(15 \%) \text {. }\end{array}$ \\
\hline
\end{tabular}

palliative radiotherapy was allowed for any bone lesion onstudy, and a variable number of lesions was irradiated in each patient to stimulate an immune response, using doses equivalent to external beam palliative radiotherapy. Thus, different numbers of patients in each treatment arm may have received different doses of radiation, and the risk of bias due to inter-arm unbalanced radiation treatment may be high.

\section{Effects of interventions}

The ten articles included in the present review reported the data of five clinical trials. A total of 5047 patients 
Table 3. Summary of findings table for the pooled analysis of COU-AA-30112 and TAK-70016 studies.

\begin{tabular}{|c|c|c|c|c|c|c|}
\hline \multirow{3}{*}{ Outcomes } & \multicolumn{2}{|c|}{ Illustrative comparative risks (95\% Cl) } & \multirow{3}{*}{$\begin{array}{l}\text { Relative effect } \\
\qquad \text { (95\% Cl) }\end{array}$} & \multirow{3}{*}{$\begin{array}{l}\text { No of } \\
\text { Participants } \\
\text { (studies) }\end{array}$} & \multirow{3}{*}{$\begin{array}{l}\text { Quality of } \\
\text { the evidence } \\
\text { (GRADE) }\end{array}$} & \multirow{3}{*}{ Comments } \\
\hline & Assumed risk & Corresponding risk & & & & \\
\hline & Placebo & $\begin{array}{l}\text { Androgen synthesis } \\
\text { inhibitor }\end{array}$ & & & & \\
\hline Overall survival & ND & ND & $\begin{array}{c}\text { HR } 0.76 \\
(0.67 \text { to } 0.87)\end{array}$ & $\begin{array}{c}2294 \\
\left(2 \text { studies }^{12,16}\right)\end{array}$ & $\begin{array}{c}\oplus \oplus \oplus \odot \\
\text { moderate }^{1}\end{array}$ & $\begin{array}{l}\text { Heterogeneity was found for } \\
\text { this comparison }\left(l^{2}=82 \%\right) \text {. } \\
\text { Sensitivity analysis was not } \\
\text { performed due to the low } \\
\text { number of studies. }\end{array}$ \\
\hline $\begin{array}{l}\text { Radiographic } \\
\text { progression-free } \\
\text { survival }\end{array}$ & ND & ND & $\begin{array}{l}\text { HR } 0.70 \\
(0.63 \text { to } 0.77)\end{array}$ & $\begin{array}{c}2294 \\
\left(2 \text { studies }^{12,16}\right)\end{array}$ & $\begin{array}{l}\oplus \oplus \odot \odot \\
l 0 W^{2}\end{array}$ & $\begin{array}{l}\text { Heterogeneity was found for } \\
\text { this comparison }\left(I^{2}=48 \%\right) \text {. } \\
\text { Sensitivity analysis was not } \\
\text { performed due to the low } \\
\text { number of studies. }\end{array}$ \\
\hline $\begin{array}{l}\text { Adverse effects - } \\
\text { Hypertension, } \\
\text { grade } 3 \text { or higher }\end{array}$ & 9 per 1000 & $\begin{array}{l}21 \text { per } 1000 \\
(9.38 \text { to } 47.6)\end{array}$ & $\begin{array}{c}\text { RR } 2.29 \\
(1.02 \text { to } 5.17)\end{array}$ & $\begin{array}{c}2280 \\
\left(2 \text { studies }^{12,16}\right)\end{array}$ & $\begin{array}{l}\oplus \oplus \oplus \oplus \\
\text { high }\end{array}$ & $\begin{array}{l}\text { No heterogeneity was found } \\
\text { for this comparison }\left(l^{2}=0 \%\right) \text {. }\end{array}$ \\
\hline $\begin{array}{l}\text { Adverse effects - } \\
\text { Hypokalemia, } \\
\text { grade } 3 \text { or higher }\end{array}$ & 5 per 1000 & $\begin{array}{c}30 \text { per } 1000 \\
(10.9 \text { to } 84.3)\end{array}$ & $\begin{array}{c}\text { RR } 5.75 \\
\text { (2.08 to } 15.90)\end{array}$ & $\begin{array}{c}2280 \\
\left(2 \text { studies }^{12,16}\right)\end{array}$ & $\begin{array}{l}\oplus \oplus \oplus \oplus \\
\text { high }\end{array}$ & $\begin{array}{l}\text { No heterogeneity was found } \\
\text { for this comparison }\left(l^{2}=0 \%\right) \text {. }\end{array}$ \\
\hline $\begin{array}{l}\text { Adverse effects - } \\
\text { Pain in extremities, } \\
\text { grade } 3 \text { or higher }\end{array}$ & 40 per 1000 & $\begin{array}{l}22 \text { per } 1000 \\
(13.5 \text { to } 35.2)\end{array}$ & $\begin{array}{c}\text { RR } 0.55 \\
(0.34 \text { to } 0.89)\end{array}$ & $\begin{array}{c}2280 \\
\left(2 \text { studies }^{12,16}\right)\end{array}$ & $\begin{array}{c}\oplus \oplus \oplus \oplus \\
\text { high }\end{array}$ & $\begin{array}{l}\text { No heterogeneity was found } \\
\text { for this comparison }\left(l^{2}=0 \%\right) \text {. }\end{array}$ \\
\hline
\end{tabular}

Cl: Confidence interval; HR: Hazard Ratio; RR: Risk Ratio; ND: Not Determined.

${ }^{1}$ Downgraded for considerable heterogeneity (-1).

2 Downgraded for high risk of attrition bias (-1) and moderate heterogeneity (-1).

The corresponding risk (and its 95\% confidence interval) is based on the assumed risk in the comparison group and the relative effect of the intervention (and its 95\% Cl).

GRADE Working Group grades of evidence.

High quality: Further research is very unlikely to change our confidence in the estimate of effect.

Moderate quality: Further research is likely to have an important impact on our confidence in the estimate of effect and may change the estimate.

Low quality: Further research is very likely to have an important impact on our confidence in the estimate of effect and is likely to change the estimate.

Very low quality: We are very uncertain about the estimate.

were randomized to experimental $(\mathrm{n}=3108)$ or control interventions (placebo/active drug; $\mathrm{n}=1939$ ). Overall and progression-free survival data are presented. Due to limited space, severe (grade $\geq 3$ ) adverse effect data are presented as on-line supplementary material.

\section{Enzalutamide versus placebo (AFFIRM study)}

At interim analysis (520 death events), median overall survival was found to be prolonged in the enzalutamide arm, compared to placebo (18.4 vs. 13.6 months, respectively). The hazard ratio for death was 0.63 (95\% CI 0.53 to $0.75, \mathrm{P}<0.00001$, Figure 3) (10).

Radiographic progression-free survival was significantly prolonged in the enzalutamide arm, compared to placebo (11 vs. 5.6 months, HR: $0.40,95 \%$ CI 0.35 to 0.46 ; $\mathrm{P}<0.0001$, Figure 3).

\section{Ipilimumab versus placebo (CA184-043 study)}

The median overall survival in the ipilimumab arm was 11.2 months, compared to 10.0 months in the placebo arm, resulting in a hazard ratio for death of 0.85 (95\% CI 0.72 to $1.0 ; \mathrm{P}=0.053[\mathrm{P}=0.06$ in our analysis $]$, Figure 3 (11).

A composite PFS endpoint was adopted for the present study, and rPFS data were not available.
Abiraterone acetate versus placebo (COU-AA-301 study) Administration of abiraterone acetate plus prednisone resulted in significantly prolonged overall survival compared to placebo plus prednisone.

The median overall survival in the abiraterone arm was 14.8 months, compared to 10.9 months in the placebo arm, resulting in a significant hazard ratio of 0.65 (95\% CI 0.54 to $0.78 ; \mathrm{P}<0.00001$, Figure 3) (12-15).

Radiographic progression-free survival was significantly prolonged in the abiraterone arm, compared to placebo (5.6 vs. 3.6 months; HR for rPFS or death: 0.66, 95\% CI 0.58 to $0.75 ; \mathrm{P}<0.00001$, Figure 3 ).

\section{Orteronel versus placebo (TAK-700 study)}

The median overall survival in the orteronel arm was 17.0 months, compared to 15.2 months in the placebo arm, resulting in a hazard ratio of 0.89 (95\% CI 0.74 to $1.06 ; \mathrm{P}=0.19$, Figure 3).

The study was unblinded after crossing a futility boundary for overall survival (16).

Radiographic progression-free survival was significantly prolonged in the orteronel arm, compared to placebo (8.3 vs. 5.7 months; HR: $0.76,95 \%$ CI 0.65 to 0.88 ; $\mathrm{P}=0.0004$, Figure 3) 
Figure 3. Summary of overall survival and radiographic progression-free survival of the included studies. Since disease progression was a composite endpoint in the CA184-043 and TROPIC studies, radiographic progression-free survival data were not available. The number of randomized subjects, hazard ratios for death or progression, the 95\% confidence intervals for hazard ratios, the $Z$ value and the significance of the single comparisons are presented.

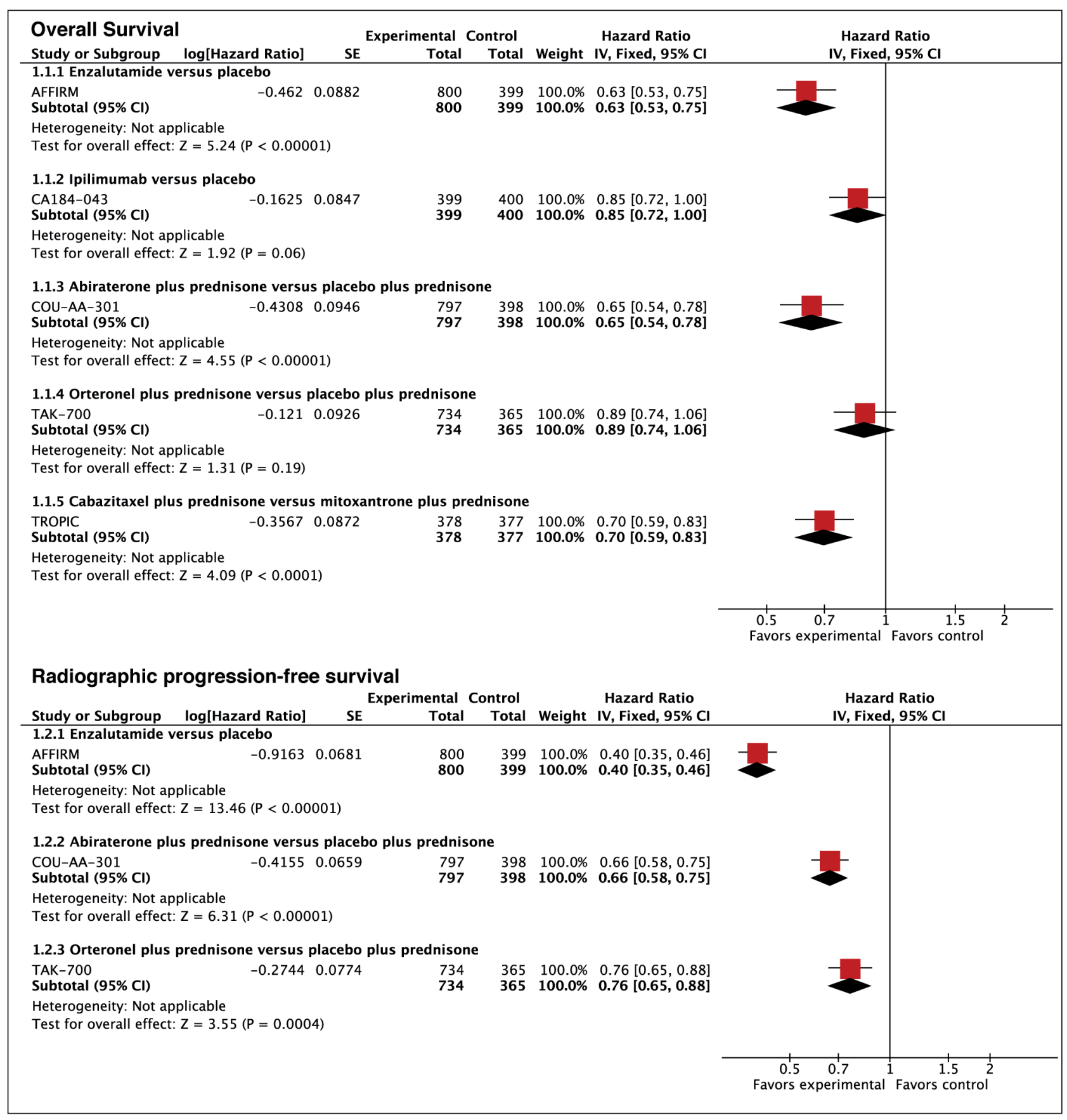

Cabazitaxel versus mitoxantrone (TROPIC study)

Treatment with cabazitaxel plus prednisone resulted in significantly prolonged overall survival compared to mitoxantrone plus prednisone. The median overall survival in the cabazitaxel arm was 15.1 months, compared to 12.7 months in the mitoxantrone arm (HR: $0.70,95 \%$ CI 0.59 to $0.83, \mathrm{p}<0.0001$, Figure 3) (17).

A composite PFS endpoint was adopted for the present study. Radiographic progression-free survival data were not available.
Intervention active on the androgen axis versus placebo (pooled analysis)

We merged two studies (COU-AA-301 and TAK-700) $(12,16)$ including in total 2294 participants (1531 in the active intervention arm, 763 in the placebo arm) treated with the androgen synthesis inhibitors (ASI) abiraterone and orteronel, showing equivalent mechanisms of action (selective inhibition 17 $\alpha$-hydroxylase and 17,20-lyase activities of CYP17A1). Both studies used placebo plus prednisone as a comparator. Analysis of overall survival 
Figure 4. Pooled analysis of overall survival and radiographic progression-free survival of the COU-AA-301 and TAK-700 studies, comparing the effect of inhibitors of the 17 $\alpha$-hydroxylase and 17,20-lyase activities of the enzyme CYP17A1, involved in the biosynthesis of testosterone, combined with prednisone, and placebo-prednisone. The number of randomized subjects, hazard ratios for death or progression, the $95 \%$ confidence intervals for hazard ratios, the $Z$ value for the overall effect, the significance of the pooled comparison and heterogeneity data (Chi2, 12), are presented. Data to left of the black line of forest plots represent greater reduction of the hazard ratios for death or progression in patients treated with androgen synthesis inhibitors. Diamonds represent pooled overall effect sizes for each outcome, which extend to the limits of the 95\% confidence intervals of hazard ratios.

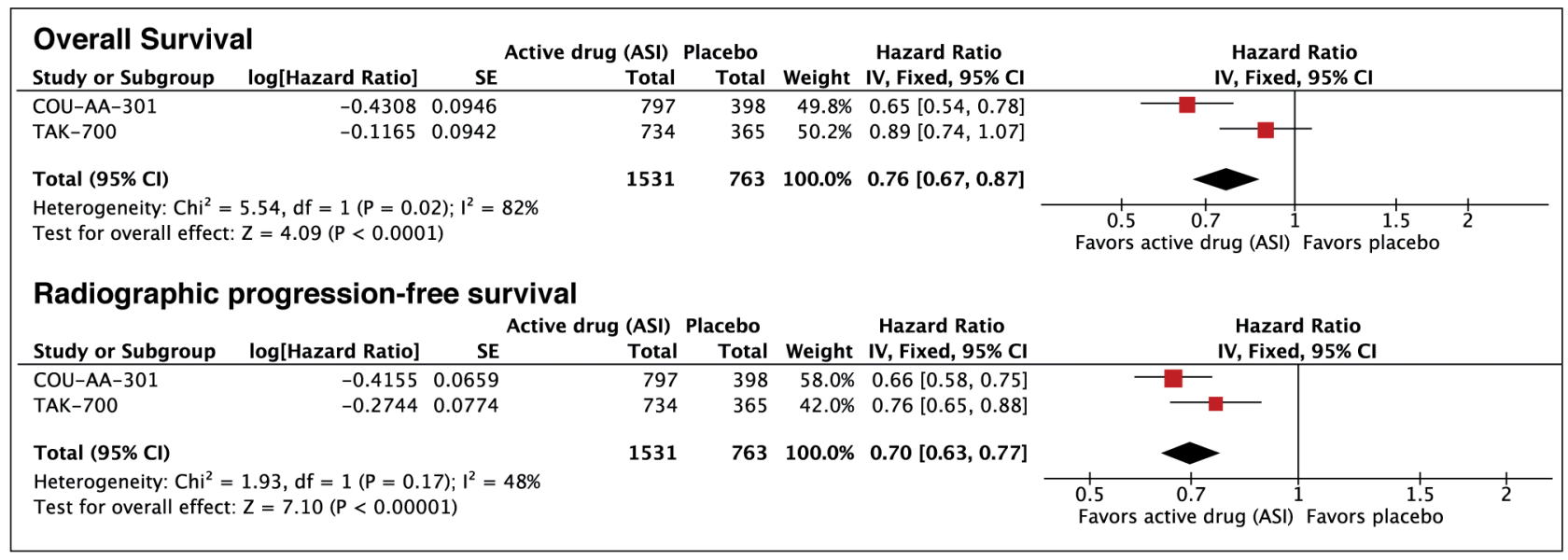

resulted in a significantly lower hazard ratio for death of ASI compared to placebo (HR: 0.76, 95\% CI 0.67 to 0.87 ; $\mathrm{P}<0.0001$, Figure 4). The quality of the evidence was moderate (Table 3). Considerable heterogeneity emerged from this analysis $\left(\mathrm{I}^{2}=82 \%, \mathrm{Chi}^{2}=5.54, \mathrm{P}=0.02\right)$.

Pooled analysis resulted in a significantly decreased hazard ratio for radiographic progression of the active interventions versus placebo (HR: $0.7,95 \%$ CI 0.63 to 0.77 ; $\mathrm{P}<0.00001$, Figure 4). The quality of the evidence was low (Table 3). Moderate heterogeneity was detected for this pooled comparison $\left(\mathrm{I}^{2}=48 \%, \mathrm{Chi}^{2}=1.93, \mathrm{P}=0.17\right)$. The number of pooled studies was not sufficient for an investigation of the causes of heterogeneity. It is conceivable that the different methods used for censoring missing data between studies may have contributed to the generation of heterogeneity. ASI induced significant increases in adverse effects linked to elevated mineralocorticoid secretion. The risk-ratio for hypokalemia was significantly enhanced in the ASI arm versus placebo (RR: 5.75, 95\% CI 2.08 to $15.90 ; \mathrm{P}=0.0008$ ). The risk ratio for hypertension, not significantly higher in each separate study, was also significantly increased in our analysis (RR: 2.29, $95 \%$ CI 1.02 to $5.17 ; \mathrm{P}=0.05$ ). Pain in the extremities was less frequently detected in the ASI arm, compared to placebo (RR 0.55, 95\% CI 0.34 to 0.89; P = 0.02). Pooled comparisons of AEs did not show heterogeneity $\left(\mathrm{I}^{2}=0 \%\right.$ in all cases). A complete list of grade $\geq 3$ adverse effects is presented as supplementary material.

\section{Discussion}

Until recently, docetaxel, administered at the standard dose of $75 \mathrm{mg} / \mathrm{m}^{2}$ every three weeks, was the only therapeutic option with proven life-prolonging efficacy for the management of mCRPC. In the last few years new agents have been approved worldwide for second-line treatment of patients affected by docetaxel-refractory
mCRPC. The present review analyzed clinical data extracted from RCTs focusing on treatment of mCRPC patients in the post-docetaxel setting.

Five studies were considered, representing a total population of 5047 patients. Different baseline characteristics between studies (e.g., the prevalence of highly-prognostic visceral metastases or severe pain at enrollment) likely explain the inter-study variability of overall survival, especially as assessed in the control arms of each trial (Table 1). In three studies, treatment with the experimental interventions could significantly prolong the median overall survival of patients. Compared to control cohorts, the survival advantages were 4.8 months for the androgen receptor antagonist enzalutamide, 4.6 months for the androgen synthesis inhibitor abiraterone and 2.4 months for the cytotoxic taxane cabazitaxel $(10,12,17)$.

Radiographic progression-free survival data were available for the enzalutamide vs. placebo comparison (rPFS advantage: 5.4 months) (10), for the abiraterone vs. placebo comparison (rPFS advantage: 2 months) (12), and for the orteronel vs. placebo comparison (rPFS advantage: 2.6 months) (16). In all cases hazard ratios were statistically significant, demonstrating the efficacy of these agents in delaying progression of the disease. All patients enrolled in the included studies had prostate cancer progressing after androgen-deprivation therapy. Three studies involved drugs acting on the androgen axis: abiraterone acetate, orteronel and enzalutamide. Pooled analysis of studies involving abiraterone acetate plus prednisone and orteronel plus prednisone confirmed that androgen synthesis inhibitors can significantly increase both overall survival and rPFS, compared to placebo-prednisone (Figure 4). Meta-analysis of overall survival contained data from a study (TAK-700) that was prematurely unblinded, due to demonstrated futility, and results must be considered conservatively. Nevertheless, the significant survival benefit resulting 
from this analysis substantiates the evidence that mCRPC is not refractory to interventions aimed at further suppressing the androgen axis in patients subjected to surgical or pharmacological castration, and shows that in these patients the androgen receptor-mediated signaling may remain functional and may actively modulate disease progression.

In addition, meta-analysis of the COU-AA-301 and TAK700 studies evidenced the appearance of severe adverse effects that can be attributed to mineralocorticoid excess, like hypertension and hypokalemia.

All experimental agents showed diverse severe adverse effects, which were lethal in some cases. Notably, cabazitaxel plus prednisone induced neutropenia of grade $\geq 3$ in $82 \%$ of cases, and grade $\geq 3$ febrile neutropenia, lethal in $5 \%$ of cases. This prompted the FDA to recommend prophylactic neutrophil growth factor support in susceptible patients (20).

Rare adverse effects worthy of further consideration were also observed in some of the included studies. For example, during the phase I-II investigation of enzalutamide, $2 \%$ of patients treated with doses $\geq 360 \mathrm{mg} /$ day had seizures (21). Although in the AFFIRM study the riskratio for seizure was not significant (10), five (or seven, according to the FDA medical review of the study) enzalutamide-treated patients had seizures, whereas in the placebo arm no seizure events were reported.

Seven patients treated with orteronel were diagnosed with pancreatitis and increased pancreatic enzyme levels. Hence, pancreas toxicity deserves further investigation and particular clinical attention.

In conclusion, several new agents have shown to be effective in prolonging survival in men with metastatic castration-resistant prostate cancer in the post-docetaxel setting. It may be hypothesized that survival may be further prolonged by combining these agents or by administering them sequentially. Randomized studies are warranted to demonstrate this hypothesis, but also to exclude reciprocal detrimental effects of these agents (22-26).

\section{ACKNOWLEDGMENTS}

We acknowledge the contributions of Dr. Philipp Dahm and Dr. Molly Neuberger, of the Cochrane Collaboration.

\section{References}

1. Bubendorf L, Schopfer A, Wagner U, et al. Metastatic patterns of prostate cancer: an autopsy study of 1,589 patients. Hum Pathol. 2000; 31:578.

2-Droz JP, Flechon A, Terret C. Prostate cancer: management of advanced disease. Ann Oncol. 2002; 13 Suppl4: 89.

3. Mottet N, Bellmunt J, Bolla M, et al. EAU guidelines on prostate cancer. Part II: Treatment of advanced, relapsing, and castrationresistant prostate cancer. Eur Urol. 2011; 59:572.

4. Tannock IF, de Wit R, Berry WR, et al. Docetaxel plus prednisone or mitoxantrone plus prednisone for advanced prostate cancer. New Engl J Med. 2004; 351:1502.

5. Mathew P, Dipaola R. Taxane refractory prostate cancer. J Urol. 2007; 178:S36.
6. Moher D, Liberati A, Tetzlaff J, et al. Preferred reporting items for systematic reviews and meta-analyses: the PRISMA statement. Ann Intern Med. 2009; 151:264.

7.Higgins JP, Altman DG, Gøtzsche PC, et al. The Cochrane Collaboration's tool for assessing risk of bias in randomised trials. BMJ. 2011; 343:d5928.

8. Niimi M, Yamamoto S, Fukuda H, et al. The Influence of handling censored data on estimating progression-free survival in cancer clinical trials (JCOG9913-A). Japan J Clin Oncol. 2002; 32:19.

9. Guyatt GH, Oxman AD, Kunz R, et al. What is "quality of evidence" and why is it important to clinicians? BMJ 2008; 336:995.

10. Scher HI, Fizazi K, Saad F, et al. Increased survival with enzalutamide in prostate cancer after chemotherapy. New Engl J Med. 2012; 367:1187.

11. Kwon ED, Drake CG, Scher HI, et al. Ipilimumab versus placebo after radiotherapy in patients with metastatic castration-resistant prostate cancer that had progressed after docetaxel chemotherapy (CA184-043): a multicentre, randomised, double-blind, phase 3 trial. Lancet oncol. 2014; 15:700.

12. de Bono JS, Logothetis CJ, Molina A, et al. Abiraterone and increased survival in metastatic prostate cancer. New Engl J Med. $2011 ; 364: 1995$.

13. Fizazi K, Scher HI, Molina A, et al. Abiraterone acetate for treatment of metastatic castration-resistant prostate cancer: final overall survival analysis of the COU-AA-301 randomised, double-blind, placebo-controlled phase 3 study. Lancet Oncol. 2012; 13:983.

14. Logothetis CJ, Basch E, Molina A, et al. Effect of abiraterone acetate and prednisone compared with placebo and prednisone on pain control and skeletal-related events in patients with metastatic castration-resistant prostate cancer: exploratory analysis of data from the COU-AA-301 randomised trial. Lancet Oncol. 2012; 13:1210.

15. Sternberg CN, Molina A, North S, et al. Effect of abiraterone acetate on fatigue in patients with metastatic castration-resistant prostate cancer after docetaxel chemotherapy. Ann Oncol. 2013; 24:1017.

16. Fizazi K, Jones R, Oudard S, et al. Phase III, Randomized, Double-Blind, Multicenter Trial Comparing Orteronel (TAK-700) Plus Prednisone With Placebo Plus Prednisone in Patients With Metastatic Castration-Resistant Prostate Cancer That Has Progressed During or After Docetaxel-Based Therapy: ELM-PC 5. J Clin Oncol. 2015; pii: JCO.2014.56.5119 [Epub ahead of print].

17. de Bono JS, Oudard S, Ozguroglu M, et al. Prednisone plus cabazitaxel or mitoxantrone for metastatic castration-resistant prostate cancer progressing after docetaxel treatment: a randomised open-label trial. Lancet 2010; 376:1147.

18. Oudard S. TROPIC: Phase III trial of cabazitaxel for the treatment of metastatic castration-resistant prostate cancer. Fut Oncol. 2011; 7:497.

19. Bahl A, Oudard S, Tombal B, et al. Impact of cabazitaxel on 2year survival and palliation of tumour-related pain in men with metastatic castration-resistant prostate cancer treated in the TROPIC trial. Ann Oncol. 2013; 24:2402.

20. Cookson MS, Roth BJ, Dahm P, et al. Castration-Resistant Prostate Cancer: AUA Guideline. J Urol. 2013; 190:429.

21. Scher HI, Beer TM, Higano CS, et al. Antitumour activity of MDV3100 in castration-resistant prostate cancer: a phase 1-2 study. Lancet 2010; 375:1437.

22. Sartor O, Pal SK. Abiraterone and its place in the treatment of metastatic CRPC. Nature Rev Clin Oncol. 2013; 10:6. 
23. Aggarwal R, Halabi S, Kelly WK, et al. The effect of prior androgen synthesis inhibition on outcomes of subsequent therapy with docetaxel in patients with metastatic castrate-resistant prostate cancer: results from a retrospective analysis of a randomized phase 3 clinical trial (CALGB 90401). Cancer 2013; 119:3636.

24. Noonan KL, North S, Bitting RL, et al. Clinical activity of abiraterone acetate in patients with metastatic castration-resistant prostate cancer progressing after enzalutamide. Ann Oncol. 2013; 24:1802.
25. Loriot Y, Bianchini D, Ileana E, et al. Antitumour activity of abiraterone acetate against metastatic castration-resistant prostate cancer progressing after docetaxel and enzalutamide (MDV3100). Ann Oncol. 2013; 24:1807.

26. Bianchini D, Lorente D, Rodriguez-Vida A, et al. Antitumour activity of enzalutamide (MDV3100) in patients with metastatic castration-resistant prostate cancer (CRPC) pre-treated with docetaxel and abiraterone. Eur J Cancer 2014; 50:78.

\section{Correspondence}

Gianpaolo Perletti, PhD, M Clin Pharmacol (Corresponding Author) gianpaolo.perletti@uninsubria.it

Elena Monti, PhD

Emanuela Marras, PhD

Biomedical Research Division, Dept. of Theoretical and Applied Sciences Università degli Studi dell'Insubria

Via A. da Giussano, 10 - 21052 Busto Arsizio, Italy

Anne Cleves, Msc

Cancer Research Wales Library, Cardiff University Velindre Hospital Cardiff, UK

Vittorio Magri, MD

Urology Secondary Care Clinic, Istituti Clinici di Perfezionamento

Milano, Italy

Alberto Trinchieri, $M D$

Urology Unit, A. Manzoni Hospital, Lecco, Italy

Paul S Rennie, PhD, FCAHS

Vancouver Prostate Centre, University of British Columbia

Vancouver, Canada 